\title{
METHODOLOGICAL INSTITUTIONALISM AS A NEW PRINCIPLE OF COMPLEX SOCIAL SYSTEMS' ANALYSIS AT MESO-LEVEL ${ }^{1,2}$
}

\author{
Svetlana G. KIRDINA, \\ Doctor of Sociology, Head of Sub-Division \\ for Evolution of Social and Economic Systems, Institute of Economics, \\ Russian Academy of Sciences - RAS, Moscow, Russia, \\ e-mail: kirdina@bk.ru
}

This inquiry emphasizes the importance of the meso-level of complex social systems analysis. It is known that most frequently two levels of analysis are presented in economics and social science - micro- and macro-. Micro-level requires consideration of the behaviour of individual actors, such as homo economicus, firms, households and others. At the macro-level societies and economies are presented as holistic social systems with their inherent laws of development. For the micro-level of social complex systems analysis the principle of methodological individualism is particularly relevant, whereas the holism principle is significant for the macro-level. Discussion around these two basic principles has been one of the crucial points in sociology and economics for many years.

However, the development of the institutional approach in economics and sociology, especially in the last decade, focuses the attention of researchers more and more on the examination of the meso-level of complex social systems. We understand the meso-level to be a space of rules, regulations, agreements, etc. - in other words, institutions in the broad sense of the term. On the one hand, these institutions are created as a result of joint activity of micro-level actors. On the other hand, institutions serve as frameworks for their performance. Further, institutions are the mechanisms which generate macrostructures with their own characteristics. An overview of current Russian and foreign publications, in the field of neoinstitutional economics and neo-institutional sociology, shows that the meso-level of complex social systems requires a new analytical principle, namely, the principle of methodological institutionalism. The essence of methodological institutionalism is to analyze and explain social phenomena in terms of operations and changes in institutional structures that form the meso-level of complex social systems. Thus, to a set of traditional analytical principles such as methodological individualism and holism, it is proposed to add a new principle of methodological institutionalism.

Keywords: meso-level social analysis; methodological individualism; methodological institutionalism; holism; complex systems' analysis

JEL classifications: $B 4, B 52$

\footnotetext{
${ }^{1}$ This research was supported by the Russian Foundation for Humanities, project No. 14-02-00422.

${ }^{2}$ My grateful thanks to Colin Chandler for his help with the English translation of the paper.

(C) С.Г. Кирдина, 2016
} 


\title{
МЕТОАОАОГИЧЕСКИЙ ИНСТИТУЦИОНААИЗМ: НОВАЯ ПРЕАПОСЫИКА АНААИЗА САОЖНЫХ СОЦИААЬНЫХ СИСТЕМ НА МЕЗОУРОВНЕ
}

\author{
С.Г. КИРДИНА, \\ доктор социологических наук, \\ завсектором эволюции социально-экономических систем, \\ Институт экономики Российской академии наук, \\ г. Москва, Россия, \\ e-mail: kirdina@bk.ru
}

В статье обсуждаются методологические вопросы анализа сложных социальных систем на мезоуровне. Известно, что наиболее часто выделяются два уровня анализа - микро- и макро. Микроуровень предполагает рассмотрение поведения индивидуальных субъектов, таких как һото есопотісия, фирмы, домохозяйства и др. На макроуровне общества или экономики представлены как целостные социальные системы с присущими им закономерностями развития. В статье доказывается, что для микроуровня анализа сложных социальных систем адекватным является принцип методологического индивидуализма. Соответственно, для анализа на макроуровне целесообразна опора на методологический принцип холизма. Дискуссия по поводу этих двух основных принципов является одним из центральных моментов методологических дебатов в социологии и экономике уже многие годы.

однако развитие институциональных подходов в экономике и социологии, особенно в последнее десятилетие, все более фокусирует внимание исследователей на рассмотрении мезо-уровня сложных социальных систем. Под мезоуровнем понимается пространство правил, норм, соглашений и m.n., другими словами - институтов в широком значении этого термина. С одной стороны, институты создаются в результате совместной деятельности субъектов микроуровня. С другой стороны, они выступают в качестве ограничений их деятельности. В-третьих, институты представляют собой механизмы, действие которых порождает макроструктуры с собственными свойствами, несводимыми к свойствам образующих их элементов. Как показывает приведенный в статье обзор актуальных зарубежных и российских публикаций в сфере неоинституциональной экономики и неоинституциональной социологии, мезоуровень анализа сложных социальных систем требует выделения адекватного этому уровню нового аналитического принципа, а именно - принципа методологического институционализма. Суть методологического институционализма состоит в исследовании и объяснении общественных явлений в терминах функционирования и изменения институциональных образований, формирующих мезоуровень сложных социальных систем. Таким образом, набор традиционных аналитических принципов, таких как методологический индивидуализм и холизм, предлагается дополнить необходимым принципом методологического институционализма.

Ключевые слова: мезоуровень социального анализа; методологический индивидуализм; методологический институционализм; холизм; анализ сложных систем 


\section{Introduction}

In economics, as well as in sociology, methodological debates are frequently topics of discussion. Specific attention focuses on clarifying analytical schemes and main epistemological principles. For the majority of economists, as is often mentioned, it is connected with "their views on causality and their predilection for methodological and theoretical precision over a search for real-world accuracy" (Fourcade at al., 2014. P. 5). So adequacy of the methodological presuppositions is assumed as most significant for the understanding of economic processes. It "permits economists to strip away complexity. Complexity may add to the richness of description, but it also prevents the analyst from seeing what is essential" (Lazear, 2000. P. 100).

Methodology is also being discussed by international and national sociological communities, including that of Russia (Podvoisky, 2011; Toshchenko, 2009, 2013, etc.). Among the major methodological issues is the development of a conceptual apparatus for sociology to reflect the research paradigms which are used and the reliance on certain basic postulates or methodological principles.

This area is seen to have accumulated certain problems requiring a solution. As early as in 2009, Russian sociologist Jan Toshchenko wrote: "The issue of a conceptual apparatus in the national sociology has not been discussed for a long time. It has been spoken of as something taken for granted" (Toshchenko, 2009. P. 7). A certain chaotic tendency in sociological terminology is also noted. "The language of sociology is not strictly and systematically inventoried. Its conceptual apparatus does not look like a tool bag, where all objects are kept clean and tidy, laid out across the cells, and are used strictly for their intended purposes, etc.", Denis Podvoisky states (Podvoisky, 2011. P. 5).

The weakness of the methodological tools is rightly attributed to the side effects of the national sociology. The vulnerability of its methodologies is that they do not allow the gap to be bridged between theoretical and conceptual innovations and empirical research. "A careless attitude to the original methodological wordings, and an omnivorous and eclectic use of different approaches, results in the creation of inedible "salads" which contributes to the profanation of the science, gives nothing to the practice, and generally discredits sociology" (Toshchenko, 2013. P. 10). On top of that, for research in social science, the relevance and quality of insights is often defined not only by the methodological elaboration level of the concepts raised, but by external factors, including the hierarchical structure of the science (Orekhovsky, 2015. P. 21).

Insufficient elaboration of methodological statements is also being discussed by the "neighbours" of sociologists - economists - who believe it has been the reason for the lack of an "explanatory aspect" and unviable practical recommendations for economic theory for decades (Blaug, 1997; see also Davar, 2015; Mirowski, 2013). Proponents of different economic approaches "have so far failed to provide a valid explanation of what (if anything) distinguishes their approach, in terms of assumptions, theories or methods..., to provide a clear and convincing picture of its own conceptual and theoretical boundaries" (Hodgson, 2014. P. 605). Therefore, economists write that a "global methodological cleansing' (Balatsky, 2012. P. 148) and the improvement of methodology, in line with the challenges of a multidimensional and interdependent world, is required.

The consistency of theoretical and methodological problems faced by economics and sociology, the genetic commonality ${ }^{3}$ and interdependency of the domains of these sciences, suggests that traditional boundaries between social disciplines increasingly blur as they share common study subjects and empirical bases, often using identical analytical apparatus. Therefore, "the conditions for the formation of common social analysis as the science of the operation and development of public institutions and the behaviour of the human groups that exist within these institutions have been created" (Polterovich, 2011.

\footnotetext{
${ }^{3}$ The same scientists - from Aristotle to Karl Marx and Thorstein Veblen - often acted as the forerunners and the classic bases of economics and social science.
} 
P. 101). In my opinion, this commonality is best characterized by the economic and sociological research which is based on the institutional approach. This paper summarizes the methodological studies both in the area of (neo) institutional sociology and (neo) institutional economics which can be considered as sections of social analysis.

\section{Levels and methodological principles of social analysis}

Applying micro-, meso- and macro-levels of analysis in the social sciences is a generally accepted method. Traditionally, the levels are divided by the scale principle. The micro-level involves a consideration of individual subjects such as individuals, households, companies, firms, etc. The macro-level is on a large scale and is usually represented by the nation, society as a whole, the economy in a national or global context, etc.

Using this approach, sociologists treat the meso-level as an intermediate group level, which links the clans, populations of settlements from a village or city to the state, region, republic, etc. In economics, the meso-level is usually understood as the part of the economy controlled by large corporations. However, since the 1990s the term has been used more broadly to indicate the analysis level between the economy of the country as a whole and the level of individuals, companies and households - this includes industries or regional economic complexes.

It is common that usually only the micro- and macro- levels are traditionally considered in social and economic analyses. Even the courses and textbooks on Economics are traditionally divided into "Macroeconomics" and "Microeconomics" and do not consider the meso-level.

The nature of basic methodological discussions also provides evidence of the dominant division into micro- and macro- levels (without consideration of the meso-level). For many years, such discussions have focused on examining the principles that are most relevant to these two levels i.e. methodological individualism and methodological holism, or reductionism and holism, or individualism and structuralism, respectively ${ }^{4}$.

The principle of methodological individualism in sociology and economics most appropriate for analyzing micro-level problems was developed by German sociologist Max Weber and introduced to economics by his follower Joseph Alois Schumpeter. It was Schumpeter who used this term "methodological individualism" in 1908 (Schumpeter, 1980 [1908]; see also Udehn, 2001. P. 214), referring to his teacher's works.

Methodological individualism is associated with the epistemological prerequisite for reductionism. It contends that social reality is described and analyzed through the reduction of all its complexities to the level of individual behaviour analysis. As Schumpeter wrote, "we have to start from the individual. ... the same reasoning cannot be applied directly to society" (Schumpeter, 1909. Pp. 215, 231). This principle is used "for the special purposes of a particular set of investigations ... to start from the given behaviour of individuals without going into the factors that formed this behaviour ... In this case we speak of Methodological Individualism" (Schumpeter, 1986. P. 889).

The importance of the principle of methodological individualism has been pointed out by many well-known figures like Max Weber, John Watkins (Watkins, 1952), Karl Popper (Popper, 1957), Geoffrey Hodgson (2007), etc. Methodological individualism characterizes "the theoretical positions based on the fact that adequate sociological assessments necessarily imply an appeal to the people, the interpretation of their obligations and the causes and reasons for actions taken" (Big Explanatory Dictionary of Sociology, 1999. P. 416).

Alongside Weber, the other founder of sociology, the French philosopher Emile Durkheim, wrote as early as in the late XIX century that society is a reality sui generis ("as it is"), which is not derived from the properties of actors acting in the society (Durkheim,

\footnotetext{
${ }^{4}$ As Wayne D. Parker notes, there are important metatheoretical connections between methodological individualism and the concepts of atomism, reductionism and formism, just as there are connections between methodological holism and the concepts of organicism and structuralism (Parker, 2006. P. 2).
} 
[1895] 1938). So he was the first to formulate the theoretical assumption of "methodological collectivism" or "holism" in sociology.

In economics the term holism was introduced by representatives of institutional economic theory, more precisely, the American traditional, or original institutionalism. Allen Gruchy (Gruchy, 1947) became a pioneer in the use of the term holism.

For many years there has been an ongoing debate between representatives of the holistic approach with the requirement to "consider social phenomena as a phenomenon of social integrity without reducing it to individual actions" and supporters of methodological individualism "with an accent on explanation solely through the actions of individuals" (Rubinstein, 2008. P. 16), as well as disputes as to which of the methodological guidelines is more relevant.

Efforts once again are under way to overcome the dominant "micro-macro" dichotomies through the construction of "synthetic", "integrative" and other approaches which, in my opinion, have still not reached their set goals (see Kirdina, 2013; 2015). For example, as argued by Margaret Archer from the United Kingdom, in sociology "no one has yet been able to pass between the Scylla and Charybdis of individualism and holism" (Archer, 1995. P. 5) $)^{5}$. It is associated with micro- and macro-level distinction of a kind which is not unique to social phenomena. Methodologists of not only the social, but also the natural sciences, state that the theories of macro- and micro-levels are often incompatible with each other because they are based on different assumptions or methodological principles (Hawking, 1996).

Also note that the issues of "transition" from micro- to macro-level of analysis have been poorly addressed so far. The mechanical aggregation (additive approach), or attribution of individual subject characteristics to a macro-subject which involves identification of collective behaviour laws with individual behaviour laws, are among the most common practices. This "approach to economic problems through studying certain aggregated processes" is based on methodological individualism (Heilbroner, 1970. P. 21), while "(M) acroeconomic dynamics is generated ...via simple aggregation of individual behaviours" (Dosi, 2011. P. 26), and continues to dominate in economics.

In sociology, as Göran Therborn rightly says, the levels of analysis of actual human social action and the results of human social actions (Therborn, 1991) are still clearly separated, so therefore all the various sociological explanations are placed between two poles and the corresponding methodological principles of either individualism or holism. Even in the first outstanding "neoclassical sociological synthesis", which Therborn connects with the great American Sociologist Talcott Parson's work Structure of Social Action (Parsons, 1937), although he (Parsons) established the "coordinate system", he focused only on the points of this system, namely, the values and norms of the existing social actors (Therborn, 1991. P. 183).

So, the meso-level of social analysis is often understood either as a group, i.e. the "middle" level of aggregation of individuals (or other social and economic actors) or "disappears" and is not seen against the background of the micro- and macro-levels, and therefore is often ignored.

\section{2. "Institutionality" of the meso-level of social analysis}

As the institutional approach in sociology and economics develops, the view of the meso-level has undergone certain changes in recent years. A proper institutional approach is only partly associated with the fact that institutions serve the specific subject of analysis.

\footnotetext{
${ }^{5}$ As Archer noted, scientists working towards the synthesis of two approaches sooner or later lost their presence of mind, and hastened to take refuge: some in the camp of individualism, others in the camp of holism (Archer, 1995). On the one hand, she gives the example of Walter Buckley (Buckley, 1967), who eventually gave up the analysis of social structures as "abstract constructs," keeping to the position of methodological individualism. On the other hand, there is a contrasting example of Peter Blau (Blau, 1964), who, contrary to the objectives of interrelated analysis, appeared, according to Archer, to have been taken captive by the holistic approach.
} 
In sociology, which Emile Durkheim called the "science of institutions, their genesis and their functioning" (Durkheim, [1895] 1938. P. Ivi), research about institutions is not new. A similar situation exists for economics. More than half a century ago David Hamilton noted in his article "Why is Institutional economics Not Institutional?" that an "institution" is one of the main concepts studied in all the social sciences. Therefore, he objected to the allocation of a particular "institutional approach" in economic science as mindless "multiplying entities" (Hamilton, 1962).

However, today "(neo)institutional sociology" and "(neo)institutional economics" are recognized perspectives in both disciplines: sociology and economics ${ }^{6}$. Apart from their association with more in-depth attention to the study of institutions as a traditional subject of research in social analysis, the formation of these perspectives is also caused by specific focuses and applied methodological principles. In my opinion, the meso-level becomes the subject of special consideration in new institutional sociology and within the framework of heterodox, especially institutional and evolutionary, economic theory. It is treated as the sphere of rules, particularly institutions, in accordance with which individuals or groups (micro-level) are acting, creating certain results (the structure of the macrolevel) in the course of joint activities ${ }^{7}$. In sociology this approach gains acceptance in the concept of organizational fields, when it comes to "the locus of an organizational field as an intermediate unit between, at the micro-level, individual actors and organizations and, at the macro- level, systems of societal and trans-societal actors" (Scott, 2008. P. 191).

The new institutionalism in sociology, which announced itself during the period from the end of the 1980s to the early 1990s, explores the most diverse phenomena at the meso-level, which include such institutional arrangements as formal and informal rules, a variety of "fields" and "local orders", conventions, etc. In his review, Russian sociologist Vadim Radaev (Radaev, 2002. Pp. 5-13) highlights, inter alia, the works of Paul DiMaggio and Walter Powell (DiMaggio and Powell, 1983), who were among the first to introduce the concept of "organizational fields." Radaev also cites the works of American researcher Neil Fligstein who replaced the concept of structures as abstract items with the concept of "fields" as local orders. The latter represent the arenas for interaction of actors, where institutions are created and reproduced (Fligstein, 2001). In other words, local orders are formed by institutionally conditioned action schemes (Radaev, 2002. P. 13). The representatives of new French institutionalism, Luc Boltanski and Laurent Thévenot, should also be highlighted. Their theory of conventions considers multiple orders of worth associated with different worlds (Boltanski and Thévenot, 1999). The conflict between the various orders of worth brings to the forefront the issue of compromise agreements and methods for coordination of economic interactions (Radaev, 2002. P. 6-7) at the meso-level.

The institutional meso-level also becomes the subject of study for economists, first of all in heterodox economic theory. Timur Gareev from Russia notes that "the current phase is characterized by the greater willingness of heterodox economics to focus on meso-levels of analysis" (Gareev, 2010. P. 55). "In fact, a study of meso-economic structures, - Russian economist Georgy Kleiner writes, - is equivalent to the study of institutions... Mesoeconomics is a natural field for the formation and operation of economic institutions" (Kleiner, 2003. P. 16). Sociologists are developing the notion that an economic system comprises structures of rules, and these rules define further the nature of the economic system, forming the meso-level (Dopfer, Foster and Potts, 2004:263; Dopfer, 2008). From this point of view, the economy, for example, does not constitute interacting agents, but the rules according to which they interact (Dosi, 2011). Wolfram Elsner from Germany believes that a real analysis of complex systems, including social and economic systems, may

\footnotetext{
${ }^{6}$ Researchers have noted a kind of "institutional boom", resulting in the formation of a variety of institutionalisms - historical, rational choice institutionalism, economic, sociological, etc. (Gareyev, 2010. P. 50; Fligstein, 2001. P. 29).

In the USSR, a similar approach, in my view, began to develop in the studies of the "social mechanism of economic development" (Zaslavskaya, 1985) by the Novosibirsk School of Economic Sociology, as well as of the political economy of socialism, at the end of the Soviet era in research devoted to the analysis of so called "economic mechanisms".
} 
be implemented only at the meso-level, where institutions for co-ordinating individual and group actions are created. Endogenous processes of interactive problem-solving of interdependent agents, in their struggle for coordination under strong uncertainty, must and can be explained at the meso-level (Elsner, 2007; 2010; 2014). Institutionalization is a process by which rules move from abstractions to being constitutive of repeated patterns of interaction in fields (Jepperson, 1991). Institutions, rules and procedures form a kind of network (a social fabric matrix), inside of (and using) which political decisions are taken (Hayden, 2006), social interactions are implemented, expectations are formed, etc.

\section{Methodological institutionalism}

The meso-level of social and economic systems may be distinguished as a specific subject of study, and its detailed study became possible because a different view (which Schumpeter defined by the term "vision") of social reality has gained acceptance. In this view, authors distinguish institutions (organizational fields, local orders, institutional matrixes) as an independent factor and the main reason for the differences between observed social and economic phenomena. In other words, researchers rely on certain assumptions, the initial methodological principles that can be unified by methodological institutional$i \mathrm{sm}^{8}$. If, for example, those who firmly uphold the position of methodological individualism are mainly interested in the study of attitudes and behavior of individuals, then the main attention from the methodological positions of institutionalism is focused on the context within which individuals act (and which they create), such as systems of rules, conventions, and institutions. Methodological institutionalism is understood as an approach to the study of any social system, including an economic one, in terms of formal and informal regulations (institutions) supporting its integrity and development, and the explanation of social and economic phenomena in terms of operation and changes of these institutional arrangements.

In my opinion, methodological institutionalism as a prerequisite for specific analysis was formed due to the separation of actual institutions (rules) from the organizations operating according to these rules, which is implemented in institutional economics and sociology. This separation was first founded and explained by Douglas North from the US (North, 1990) and then accepted by the broader scientific audience worldwide. As regards the prerequisite for methodological institutionalism, it is not yet formally under discussion.

Papers by Piet Keizer from the Utrecht University (Netherlands), dedicated to the methodological analysis of studying institutions in sociology and economics, are rare works where, among other things, the term "methodological institutionalism" has been introduced and discussed (Keizer, 2007; 2008; 2015). For him, methodological institutionalism is, first of all, a level of explanation of a well-established phenomenon, and connectivity between rules operating at this level, whether we are talking about the rules inside the firm or at the macro-level (Keizer, 2007. P. 3-14; Keizer, 2008. P. 14). The challenge is to identify the most stable institutional level, which regulates the activities of some or other actors, and then to study that level.

In general terms, I agree with the position of Keizer. At the same time, he propounds that "methodological institutionalism synthesizes the macro-approach or methodological collectivism, and the micro-approach or methodological individualism. This synthesis also solved the divide between the logical versus the historical approach" (Keizer, 2007. P. 20), removing the contradiction between the micro- and macro-levels (Ibid.), and was surprising, and makes Keizer's position unclear, and his logic purely formal.

In my opinion, the problem is more complicated. The transition from micro-to mesoand macro-levels of analysis is not associated with either "aggregation of individuals" or

\footnotetext{
${ }^{8}$ Unlike the term "methodological institutionalism" in scientific studies in Russia, when analyzing the development of the scientific areas we are talking about - "the institutionalization of methodologies", that characterizes the structure and the development of science (Frolov, 2002; 2008; Maracha, 2003).
} 
"synthesis". Each time it is a transition to the new essence or property. The principle of methodological institutionalism allows us to "catch" this new institutional essence, characterizing the meso-level and not represented directly at the level of individuals (microlevel) or at the level of the generated macro-environment (Table 1).

Table 1

Levels, subjects and dominant methodological principles of social analysis

\begin{tabular}{|c|c|c|}
\hline Level & Subject & Methodological principles \\
\hline Macro- & $\begin{array}{c}\text { Societies, social structures, } \\
\text { national or global economic } \\
\text { systems... }\end{array}$ & Holism \\
\hline Meso- & $\begin{array}{c}\text { The relationships between social } \\
\text { and economic actors (institutions, } \\
\text { local orders, organizational fields, } \\
\text { institutional matrices)... }\end{array}$ & Methodological institutionalism \\
\hline Micro- & $\begin{array}{c}\text { Individuals, economic agents, } \\
\text { households, families, companies, } \\
\text { nation-states as units... }\end{array}$ & $\begin{array}{c}\text { Methodological } \\
\text { individualism }\end{array}$ \\
\hline
\end{tabular}

The table shows the levels of social analysis and the most relevant methodological principles (preconditions) for their research. Of course, macrostructures might also be studied from the standpoint of methodological individualism (more typical for micro-level studies) by likening them to social actors with certain interests, expectations and behaviours. One can also explore individuals from the standpoint of methodological institutionalism, appealing to the reflection of the institutional systems of societies in the individual conscience (see, for example, Homo institutius, 2005). However, the relevance of the levels and the premises of social analysis as represented in the table are the most common and set the corresponding perspective of studies.

I have to note that the understanding of methodological institutionalism presented in this paper develops those outlined in my earlier works (Kirdina, 2013). It then appeared that methodological institutionalism could be interpreted as the implementation of the holism principle in relation to the analysis of social and economic systems. However, a more thorough analysis of works in the field of (neo) institutional sociology and (neo) institutional economics shows that methodological institutionalism does not specify a prerequisite for holism, but complements the existing set of prerequisites for social analysis such as methodological individualism and holism. Its main application is a meso-, rather than a macro-level of analysis of socio-economic systems.

\section{Conclusion.}

The development of the institutional approach in economics and sociology led to a new understanding of the meso-level as a space for creating rules according to which and where actors operate, generating macrostructures. The new institutional theories widespread in social sciences are largely different. However, "they all agree on the fact that social institutions generate social local orders and are social constructions" (Fligstein, 2001. P. 28). Locality in this case means belonging to the meso-level of social analysis. Thus, we can speak about revealing a new analytical assumption (or new theoretical proposition) that is most relevant to studying the meso-level, which is methodological institutionalism. It complements the space of known prerequisites for methodological individualism and holism, which are characteristic of micro- and macro-level research respectively. The 
essence of methodological institutionalism is the study and explanation of social and economic phenomena in terms of the operation and changes of the institutional arrangements which form the meso-level of complex social systems.

\section{IИTEPATYPA/REFERENCES}

Archer M. (1995). Realist social theory: the morphogenetic approach. Cambridge, New York: Cambridge University Press.

Balatsky E.V. (2012). Outside of "economic imperialism": overcoming the difficulties // Social studies and the present, no. 4, pp. 138-149. (In Russian.)

Big Explanatory Dictionary of Sociology (Collins) (1999). Vol. 1. Moscow: VECHE AST Publ. (In Russian.)

Blaug M. (1997). Economic Thought in Retrospect. Cambridge: Cambridge University Press.

Blau P. (1964). Exchange and Power in Social Life. New York: Wiley.

Boltanski L. and Thévenot, L. (1999).The Sociology of Critical Capacity // European Journal of Social Theory, vol. 2, no. 3, August, pp. 359-378.

Buckley W. (1967). Sociology and Modern Systems Theory. New York: Prentice-Hall.

Davar E. (2015). Crisis of Economic Science: Causes and Remedy // Terra Economicus, vol. 13, no. 2, pp. 73-83. (In Russian.)

Denis A. (2015). Schumpeter and the Roots of Methodological Individualism. (under consideration at Review of Political Economy) (http://www.staff.city.ac.uk/andy.denis/ research/home.htm, accessed on February 10, 2015).

DiMaggio P. and Powell W. (1983). The Iron Cage Revisited: Institutional Isomorphism and Collective Rationality in Organizational Fields // American Sociological Review, vol. 48, no. 2, pp. 147-160.

Dopfer K., Foster J., and Potts J. (2004). Micro-Meso-Macro // Journal of Evolutionary Economics, vol. 14, issue 3, pp. 263-279.

Dopfer K. 2008. The origins of mesoeconomics / In: Kirdina S. and Maevsky V. (eds.) Evolutionary theory, the theory of self-reproduction and economic development. Materials of the 7th International Symposium on Evolutionary Economics, September 14-15, 2007, Pushchino, Moscow region. Moscow: Institute of Economics, Russian Academy of Sciences Publ., pp. 101-128. (In Russian.)

Dosi J. (2011). Economic Coordination and Dynamics: Some Elements of an Alternative "Evolutionary" Paradigm. Institute for New Economic Thinking (http://www2.econ. iastate.edu/tesfatsi/EconomicCoordinationAndDynamics.GDosi2012.INET.pdf, accessed on January 29, 2016).

Durkheim E. (1938 [1895]). The Rules of Sociological Method. New York: The Free Press.

Elsner W. (2007). Why Meso? On "Aggregation" and "Emergence", and Why and How the Meso Level is Essential in Social Economics // Forum for Social Economics, vol. 36, no. 1, April, pp. 1-16.

Elsner W. (2010). The Process and a Simple Logic of "Meso". On the Co-Evolution of Institutional Emergence and Group Size // Journal of Evolutionary Economics, vol. 20, no. 3, pp. 445-477.

Elsner W. (2014). The Institutionalist Theory of Institutional Change Revisited: The Institutional Dichotomy in a More Formal Perspective / In: Kirdina S. and Maevsky V. (eds.) The evolution of economic theory: reproduction, technology, institutions. Proceedings of the IX International Symposium on Evolutionary Economics, Pushchino, September 12-14, 2013. St. Petersburg: Aletheia Publ., pp. 281-293. (In Russian.)

Fligstein N. (2001). Social Skill and the Theory of Fields // Sociological Theory, vol. 19, no. 2, pp. 105-121.

Fligstin N. (2001). Fields, power and social skills: critical analysis of the new institutional trends // Economic sociology. Electronic journal, vol. 2, no. 4, pp. 28-55. (In Russian.) 
Fourcade M., Ollion E. and Algan Y. (2014). The Superiority of Economists // MaxPo Discussion Paper, 14/3. Max Planck Sciences Po Center on Coping with Instability in Market Societies. November.

Frolov D.P. (2002). Institutionalism in the metacompetition of economic theories // Materials of the scientific session. Issue 1: Economics and Finance. Volgograd: Publishing House of Volgograd State University. (In Russian.)

Frolov D.P. (2008). The methodological institutionalism: a new perspective on the evolution of economic science // Problems of Economics, no. 11, pp. 90-101. (In Russian.)

Gareyev T.R. (2010). Institutions and economic development at the sub-regional (meso) level // Social studies and the present, no. 5, pp. 45-58. (In Russian.)

Gruchy A. (1947). Modern Economic Thought. The American Contribution. New York: Prentice Hall.

Hamilton D. (1962). Why is Institutional Economics Not Institutional? // The American Journal of Economics and Sociology, vol. 21, no. 3, July, pp. 309-317.

Hawking S. (1996). A Brief History of Time. New York: Bantam Doubleday Dell Publishing Group Inc.

Hayden G. (2006). Policymaking for a Good Society: The Social Fabric Matrix Approach to Policy Analysis and Program Evaluation. New York: Springer.

Heilbroner R. (1970). Understanding Macroeconomics. New Jersey: Englewood Cliffs.

Hodgson G.M. (2007). Meanings of Methodological Individualism // Journal of Economic Methodology, vol. 14, no. 2, June, pp. 211-226.

Hodgson G.M. (2014). On Fuzzy Frontiers and Fragmented Foundations: Some Reflections on the Original and New Institutional Economics // Journal of Institutional Economics, vol. 10, no. 4. Special issue, pp. 591-611.

Inshakov 0. (ed.) (2005). Homo institutius. Volgograd: Publishing House of Volgograd State University. (In Russian.)

Jepperson R.L. (1991). Institutions, Institutional Effects, and Institutionalism / In: Powell W.W. and DiMaggio P.J. (eds.) The New Institutionalism in Organizational Analysis, pp. 143-163. Chicago: University of Chicago Press.

Keizer P. (2007). The Concept of Institution in Economics and Sociology, a Methodological Exposition // Working Papers. 07-25. Tjalling C. Koopmans Research Institute Utrecht School of Economics, Utrecht University.

Keizer P. (2008). Economics as a Social Science. Utrecht: Utrecht School of Economics. Utrecht University, July.

Keizer P. (2015). Multidisciplinary Economics: A Methodological Account. 0xford: 0xford University Press.

Kirdina S. (2015). Methodological Individualism and Methodological Institutionalism for Interdisciplinary Research // Montenegrin Journal of Economics, vol. 11, no. 1, July, pp. 53-67.

Kirdina S.G. (2013). The methodological individualism and methodological institutionalism // Voprosy economiki, no. 10, pp. 66-89. (In Russian.)

Kleiner G.B. (2003). Meso-economic problems of the Russian economy // Economic Bulletin of the Rostov State University, vol. 1, no. 2, pp. 11-18. (In Russian.)

Lazear E.P. (2000). Economic Imperialism // Quarterly Journal of Economics, vol. 115, no. 1, pp. 99-146.

Maracha V.G. (2003). The structure and development of science from the standpoint of methodological institutionalism // Methodology of Science: Challenges and history. Moscow: Institute of Philosophy of the Russian Academy of Sciences Publ., pp. 166-220. (In Russian.)

Mirowski P. (2013). The Philosophical Bases of Istitutionalist Economics // Terra Economicus, vol. 11, no. 3, pp. 72-88. (In Russian.)

North D.C. (1990). Institutions, Institutional Change and Economic Performance. Cambridge: Cambridge University Press. 
Orekhovskiy P.A. (2015). The structure of the field of economic knowledge: Possibilities and limits of economic discussions // Social studies and the present, no. 1, pp. 5-23. (In Russian.)

Parker W.D. (2006). Methodological Individualism vs. Methodological Holism: Neoclassicism, Instit tionalism and Socionomic Theory. Paper presented at the joint annual congress of the International Association for Research in Economic Psychology (IAR EP) and the Society for the Advancement of Behavioral Economics (SABE), University of Paris (Sorbonne), Paris, France, July 5-8, 2006.

Parsons T. (1937). The Structure of Social Action. New York: McGraw Hill.

Podvoisky D.G. (2011). Languages of Sociology: verbosity or cacophony? // SOCIS, no. 5, pp. 3-9. (In Russian.)

Polterovich V.M. (2011). Formation of the general social analysis // Social studies and the present, no. 2, pp. 101-111. (In Russian.)

Popper K. (1957). The Poverty of Historicism. London: Routledge and Kegan Paul.

Radaev V.V. (2002). The main directions of development of modern economic sociology / In: Radaev V.V. (ed.) Economic Sociology, new approaches to institutional and network analysis. Moscow: ROSSPEN Publ., pp. 3-18. (In Russian.)

Rubinstein A.Y. (2008). The economy of public preferences. The structure and evolution of social interest. Saint-Petersburg: Aletheia Publ. (In Russian.)

Schumpeter J.A. (1909). On the Concept of Social Value. The Quarterly Journal of Economics, vol. 23, no. 2, February, pp. 213-232.

Schumpeter J.A. (1980 [1908]). Methodological Individualism. Brussels: Institutum Europæum (http://mises.org/books/ schumpeter_individualism.pdf, accessed on November 26, 2011).

Schumpeter J.A. (1986 [1954]). History of Economic Analysis. London: Routledge.

Scott W.R. (2008). Institutions and Organizations: Ideas and Interests. Los Angeles, CA: Sage Publications.

Therborn G. (1991). Cultural Belonging, Structural Location, and Human Action. Explanation in Sociology and in Social Science // Acta Sociologica: Journal of the Scandinavian Sociological Association, vol. 34, no. 3, pp. 177-192.

Toshchenko Z.T. (2009). Evolution of theoretical sociology in Russia (1950-2000). Article 2 // SOCIS, no. 7, July, pp. 3-16. (In Russian.)

Toshchenko Z.T. (2013). New trends in the development of Russian sociology // SOCIS, no. 4, pp. 3-12. (In Russian.)

Udehn L. (2001). Methodological Individualism: Background, History and Meaning. London: Routledge.

Watkins J.M. (1952). Ideal Types and Historical Explanation // British Journal for the Philosophy of Science, no. 3, May, pp. 22-34.

Zaslavskaya T.I. (1985). On the social mechanism of economic development // Ways of improving the social mechanism of the Soviet economy. Novosibirsk: Institute of Economics and Industrial Engineering of the Siberian Branch of the Russian Academy of Sciences Publ. (In Russian.) 